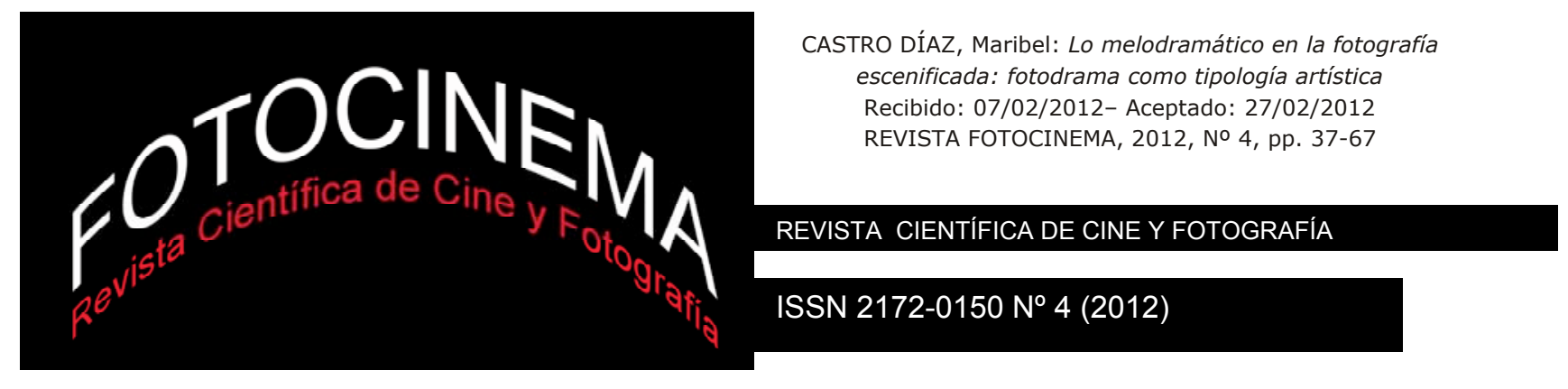

\title{
LO MELODRAMÁTICO EN LA FOTOGRAFÍA ESCENIFICADA: EL FOTODRAMA COMO TIPOLOGÍA ARTÍSTICA
}

\section{THE MELODRAMATIC IN STAGED PHOTOGRAPHY: THE PHOTODRAMA AS AN ARTISTIC TYPOLOGY}

\author{
Maribel Castro Díaz \\ Universidad Complutense de Madrid / \\ Universidad Francisco de Vitoria
}

\section{Resumen:}

En los últimos años, numerosos autores han escenificado narrativas dramáticas para la cámara inspirándose en un tipo de películas, televisión y escenas melodramáticas. Tras una definición del concepto de melodrama y de un breve recorrido por su historia y sus implicaciones estéticas, sociológicas y artísticas, este texto desarrolla esta influencia de lo melodramático en el arte actual, y en concreto, en la fotografía escenificada (también denominada teatral o narrativa), hasta el punto de convertirse en un rasgo distintivo.

A través del análisis de un conjunto de obras recientes que apuntan de diferentes maneras a cuestiones y estrategias melodramáticas se pone de manifiesto la importancia de un tipo de fotografía (a veces altamente codificada y simbólica) que enfatiza los aspectos sentimentales, la cultura popular, la intertextualidad y el artificio para narrar realidades sociales o psíquicas con enfoques críticos. Estos "fotodramas" funcionan como lenguaje visual plenamente contemporáneo, encarnando las ansiedades y problemáticas de la época post/hipermoderna.

\begin{abstract}
:
In recent years, a large number of authors have staged dramatic stories in front of the camera finding inspiration in a melodramatic kind of films, television and scenes. After a definition of the concept of melodrama and a brief overwiew of its history and its aesthetic, sociologic and artistic implications, this essay discusses the influence of the melodramatic in contemporary art, and specifically in staged photography (also known as theatrical or narrative photography), to the extent of becoming a distinctive feature.

The analysis of a group of recent works that point in different ways melodramatic issues and strategies makes clear the importance of a type of photography (sometimes highly codified and symbolic) that emphasizes sentimental aspects, popular culture, intertextuality and artifice to convey social or psychic realities with critical approaches. These "photodramas" function as a fully contemporary visual language, embodying the anxieties and problems of the post/hypermodern age.
\end{abstract}

\section{Palabras clave:}

Melodrama; fotografía escenificada; arte contemporáneo; narración

\section{Key words:}

Melodrama; staged photography; contemporary art; storytelling 


\section{El melodrama. Definición, características, actitudes}

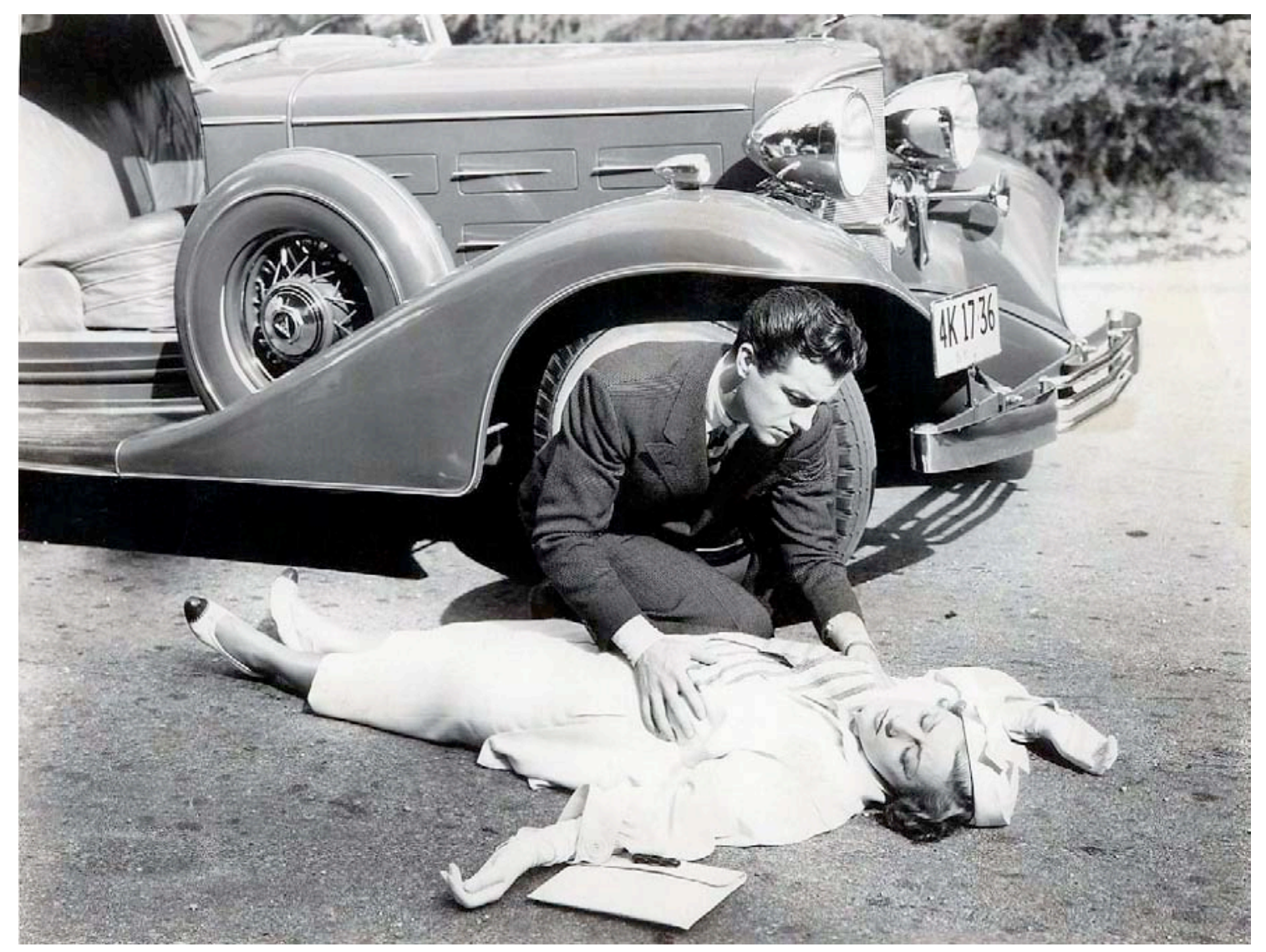

Fotograma de la película “Magnificent Obsession” (1954), de Douglas Sirk

Una característica relevante de la fotografía escenificada actual (también llamada fotografía narrativa o teatral, que aquí denominaremos "fotodrama") es la presencia de lo melodramático y sus estrategias, tanto en los asuntos tratados como en el tono o la estética.

En general, el término melodrama se refiere a la obra que exagera los aspectos sentimentales y patéticos de las situaciones con la intención de conmover a un público. Denota un tipo ficcional o teatral relacionado con la cultura popular, a caballo entre el realismo y la tragedia, manteniendo complejas relaciones históricas entre ambas. No sólo se refiere a un tipo de estética, sino a un modo de ver el mundo.

Como género popular redescubierto en los últimos años, el melodrama presenta un problema central en relación a su status; no se trata tanto de un género cinematográfico como de un modo de relato, una forma de cruce cultural con 
una compleja historia de más de doscientos años. El género melodramático permite abordar, camuflando y desenmascarando a la vez, cuestiones de deseo, placer, fantasía, estética e ideología, a través de los "héroes" melodramáticos.

El melodrama ha sido tradicionalmente identificado como un género femenino. La recuperación del realismo y de la tragedia en el cambio del siglo XIX al XX como categorías que demarcan la alta cultura frente a la cultura popular coinciden con una re-masculinización del valor cultural. Mientras la tragedia y el realismo se enfocan en asuntos sociales "serios" o dilemas internos, los sentimientos y la emotividad son reducidos a sentimentalismo y exageración, los detalles domésticos se cuentan como algo trivial, y lo melodramático se considera una fantasía de escape, totalmente devaluado al asociarse con una cultura popular "femenina". Y es que uno de los puntos de tensión del melodrama reside en su identificación con la ideología burguesa, junto con su oposición a su uso sub-cultural, particularmente ejercido por las mujeres. También el melodrama se identifica con cuestiones relacionadas con las relaciones familiares y heterosexuales. Además, el melodrama saca a la superficie asuntos de placer, fantasía, ideología y su rol en la cultura popular. Muy frecuente en el ámbito de la televisión, la teleserie o soap opera es comúnmente considerada como uno de los últimos refugios del melodrama. Ésta tiene una tradicional filiación con la cultura popular "femenina", lo cual nos ha hecho asumir ciertas cuestiones en relación al género del espectador.

Desde principios del siglo XX hasta los años 60 el melodrama es concebido en términos esencialmente peyorativos. Constituye básicamente un anti-valor para un campo crítico en el que la tragedia y el realismo representan las piedras angulares de la "alta" cultura, que necesita protegerse de la masa, del entretenimiento melodramático. En el mejor de los casos, el melodrama se considera una categoría genérica fragmentada, un modo estético un tanto perverso que rompe fronteras o convenciones de género.

Es a finales de los 60 cuando el melodrama llega a ser finalmente admitido dentro del campo del pensamiento académico, en el contexto de un debate en el que la crítica de cine anglosajona se abre al estructuralismo francés y a las estéticas neo-marxistas, reconstruyendo por completo el campo teórico. Los esfuerzos por extender en Hollywood los valores de un humanismo realista son 
cuestionados como un liberalismo desconsiderado, que ignora la producción de bienes capitalistas tanto de la clase alta, de la "alta" cultura como de la cultura de masas, y la estrecha conexión entre significación y reproducción ideológica (GLEDHILL, Christine, 1987: 5-39).

El valor estético del realismo es cuestionado en debates sobre su ingenuidad ideológica. Pero surge un nuevo énfasis en la operatividad y efectividad ideológica de la forma estética del melodrama. El melodrama presenta una contradicción formal que da lugar a un nuevo valor crítico que presenta a través de películas en apariencia cómplices ideológicamente con el statu quo, pero que encierran en realidad una crítica encubierta a éste cuando leen entre líneas.

El melodrama explota unas nuevas condiciones de producción, convirtiéndose en un lugar de transmutación genérica y de "intertextualidad". Se multiplica a través de la traducción, adaptación, y, en la ausencia de reglas de copyright, a través de la piratería también. Los clásicos dramáticos y literarios, que podían incluir tragedias de Shakespeare, ficción popular, poesía romántica y libretos operísticos, sucesos del periódico, imágenes de pinturas o grabados, canciones populares, aportan toda clase de materiales para el melodrama.

El autor que más ha hecho por rescatar el melodrama del descrédito ha sido posiblemente Peter Brooks. En su libro The melodramatic imagination (1976), texto de referencia en el tema, Brooks defiende el papel del melodrama más allá de su mera condición de espectáculo, proponiéndolo como un modo específicamente moderno que resurge de la pérdida de los valores ilustrados y de las formas simbólicas, y que funciona como respuesta a las consecuencias físicas del orden social burgués, en el que lo social debía ser expresado como lo personal.

El melodrama encubre lo que Brooks llama "lo más oculto", el dominio de unos valores que se señalan y se enmascaran a la vez, mostrando la superficie de la realidad. En el melodrama el concepto de lo reprimido está relacionado con el predominio de lo aparentemente racional y de la idea de "normalidad" relativa a los códigos de conducta social, convenciones del lenguaje y estructura de la psique. Además, el melodrama parece demandar ideas de transcendencia y valor personal, y un reconocimiento de todas aquellas cosas que no encajan 
dentro del orden dominante (como los deseos anti-sociales, lo paranormal, la ambigüedad moral...).

La herencia que el melodrama tiene de la tradición popular le permite presionar los discursos convencionales y represivos del orden post-ilustrado. Este género utiliza mecanismos narrativos que crean una barrera a la expresión, haciendo que actuaciones melodramáticas se conviertan en estrategias excesivas y alternativas que clarifican frentes dramáticos. La recurrencia del melodrama al exceso gestual, visual y musical constituye el intento expresivo de lo que Brooks llama el "texto de lo mudo": dispositivos como la pantomima, los retablos escénicos y el espectáculo llegan a alcanzar lo que no puede ser generado a partir del código del lenguaje escrito o hablado.

Según Peter Brooks, el melodrama puede ser también definido como un género que trabaja paradójicamente con la idea de represión para alcanzar una total expresividad. Brooks señala que "uno está tentado a especular que los diferentes tipos de drama tienen sus correspondientes privaciones de sentido: para la tragedia, ceguera, ya que la tragedia trata sobre la visión interior y la iluminación; para la comedia, la sordera, ya que la comedia está relacionada con problemas de comunicación, malentendidos y sus consecuencias; y para el melodrama, la mudez, ya que el melodrama trata de la expresión" (BROOKS, 1976:56).

En los comienzos del melodrama, en la Inglaterra de principios del siglo XIX, el éxito de esta nueva forma de expresión tiene su explicación en que, en un momento de extrema pobreza y monotonía, la gente ansiaba las crudezas y la violencia del melodrama, esperando del espectáculo un cierto consuelo, alguna voz de esperanza o de justicia. El melodrama, de alguna forma, supone una expresión democrática en la ilusión de posibilidad de una vida mejor para los desfavorecidos o los débiles oprimidos por las clases dominantes. La familia, con su moral y sus valores, se convierte en el centro de las tramas, que se vuelven cada vez más domésticas. El género del melodrama, obsesionado con sus propias superficies, apuesta por la exteriorización y la exageración sobre la profundidad o lo complejo. Sin embargo, también acaba por revelarse además como un importante instrumento psicoanalítico, en tanto que desea exponer lo 
profundo, sea esto psicológico o mítico, recuperando algunas de las cosas ocultas en el subconsciente.

El término de "lo popular" define un terreno en el que diferentes clases y grupos sociales se encuentran y hallan su identidad. En este sentido, hay una construcción ideológica. Lo "popular" está avocado a la tensión, esfuerzos y negociaciones. En este contexto, la heterogeneidad de la estética del melodrama facilita el conflicto y la negociación entre identidades culturales. El texto melodramático trabaja con un nivel "imaginario", inherente a la producción ficcional, pero también en un nivel realista, que remite al mundo externo al texto. Como Brooks apunta, el melodrama cubre una demanda de significados que no están disponibles dentro del discurso de lo socialmente legítimo, mediante la investigación de personajes, eventos y relaciones altamente simbolizados.

En cuanto a la negociación cultural, el melodrama trata lo socio-político sólo en cuanto afecta a lo psíquico, y la ausencia de relaciones causales entre ambos permite un cortocircuito entre el deseo melodramático y el mundo socialmente construido. En el melodrama hay una relación desajustada entre estéticas, placer e ideología. Se dice que la popularidad del melodrama suele coincidir con épocas de crisis intensa, sociológica o ideológica, y en estos contextos puede funcionar como elemento subversivo o como entretenimiento de escape, de acuerdo con las necesidades ideológicas. En cualquiera de estos casos, siempre se mantiene constante una polarización extrema de los valores (bien/mal, héroe/villano, virtuoso/corrupto...).

El melodrama nos conduce al interior de las limitaciones del statu quo, de lo ideológicamente permisible. Reconsidera demandas inadmisibles en los códigos del discurso social, psicológico o político, y sus posibilidades residen en su doble reconocimiento de cómo se han dado las cosas en la coyuntura histórica, y de cómo en ella se han contenido resistencias y deseos primarios. Esto es esencial para comprender no sólo lo que queremos cambiar, sino también las fuerzas y debilidades de las que procedemos. Sin embargo, el melodrama puede verse como un nexo contradictorio en el que ciertas determinaciones (sociales, políticas y artísticas) se relacionan, pero en el que el problema de la articulación de las mismas no se resuelve nunca con éxito. Puede que la importancia del 
melodrama resida precisamente en su fallo ideológico, en su despropósito, en el espacio abierto entre sus contradicciones.

La persistencia del melodrama indica las maneras en que la cultura popular no sólo ha tomado nota de las crisis sociales y del hecho de que los perdedores no son siempre aquellos que lo merecen más, sino que además ha renunciado a entender el cambio social si no es en contextos privados o en términos emocionales. En esto hay una saludable pérdida de confianza en la intelectualidad y en la teoría social abstracta, insistiendo en que otras estructuras de la experiencia tienen más que ver con la realidad. Al mismo tiempo, se ha criticado que el melodrama encierra una ignorancia de las dimensiones propiamente sociales y políticas de estos cambios, y su causalidad, permitiendo crecientes formas de escapismo del sistema de entretenimiento.

\section{La presencia del melodrama en el arte contemporáneo}

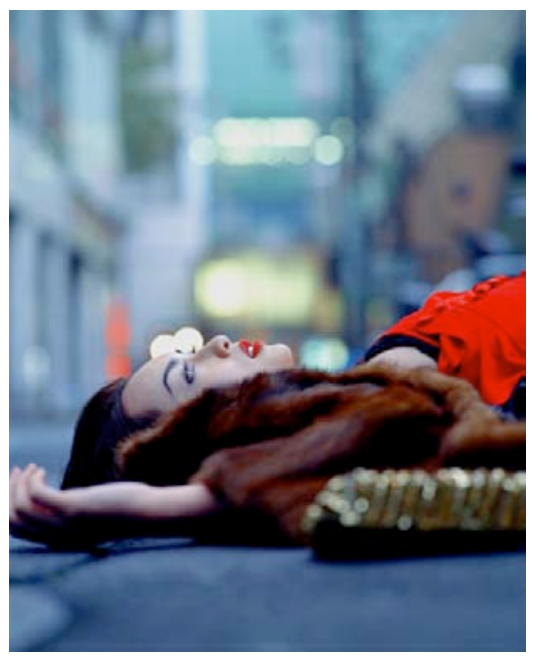

Izima Kaoru: "Hasegawa Kyoko wears Yves Saint Laurent Rive Gauche no 412" (2003)

La historia estética del siglo XIX sugiere un desarrollo de la interdependencia entre melodrama y realismo; lo que el realismo deja sin cubrir se convierte en nuevo material para el proyecto melodramático. Mientras que el proyecto realista establece que es imposible, de un modo representacional, encarnar el mundo y luego deconstruirlo para revelar su interior y sus huesos, el melodrama, por el contrario, se sitúa en el mundo material del día a día y de la 
experiencia vivida, asumiendo las limitaciones del lenguaje y de la representación.

El melodrama procede a forzar la identidad, el valor y la plenitud del significado en una presencia estética. El significante no puede cubrir las posibilidades de lo significado; el melodrama es principalmente un "lenguaje de presencia de la inmediatez". Mientras que el realismo pretende abarcar el mundo comprendiéndolo, y lo moderno y lo posmoderno exploran de maneras diferentes la desilusión derivada de esta ambición, recuperando el propósito central del melodrama, extraer el significado y la identidad de las inadecuaciones del lenguaje.

El melodrama es un modo de expresión esencialmente visual, donde colores y formas lumínicas se magnifican y se exageran, en una voluntad de resaltar los elementos constituyentes de un mundo que no pretende ser el real, sino que es como debiera ser... Y es que el melodrama, es, sobre todo, un drama de reconocimiento. Es un drama de signos, icónico, teatral y codificado.

Inevitablemente, el melodrama encuentra en las artes visuales un buen campo de acción, ya que ambos comparten diversas cualidades, entre ellas, el anhelo de trascendencia en un mundo desprovisto de lo sagrado. Mientras el melodrama busca revelar la estructura de un sistema moral a base de los principios del bien y el mal, el arte va más allá y se equipara con ese bien, con el misterio. En esta tarea heroica de recuperación de lo sublime, el melodrama fracasa en tanto que es identificado con el mal gusto y sufre el descrédito de la "cultura", y el arte es cuestionado en su intención de expresar y contener lo existencial a través de sus diferentes medios. $\mathrm{El}$ arte actual, superviviente del debate entre la estética de la alta y de la baja cultura, se ha abierto al género melodramático y explota sus virtudes (situaciones excesivas, intensificación de los sentimientos, dimensiones espectaculares...) según sus necesidades. De hecho, hoy en día vemos cómo frecuentemente el espacio del museo se convierte en todo un escenario, cómo las obras adquieren dimensiones desmesuradas que exceden el sentido del objeto, y cómo las fotografías se convierten en verdaderos espacios con vida, en escenas casi a tamaño real donde estamos invitados a entrar.

Podemos decir que el melodrama es una especie de estado mental, un modo de ser, un género. Ha estado siempre ciertamente desacreditado frente a todo lo 
que pertenece al orden de la "alta cultura" o al ámbito de lo intelectual. Pero se ha infiltrado en todos las capas de nuestra vida, en la entonación de nuestro discurso, de forma que hoy hablamos de cosas en realidad banales, calificándolas de trágicas, sublimes, malignas... Lo cotidiano se hiperboliza hasta un extremo antes desconocido. La naturaleza visual de los medios de comunicación de masas ha sido definitiva en el hecho de que el momento actual se haya vuelto melodramático. El flujo constante de comunicación e imágenes favorece el contar con la presencia constante del otro, y con el acecho constante de lo trivial. Para evitar lo trivial podemos echar mano de dos procedimientos, que son las técnicas del melodrama: o se exagera lo cotidiano, o se cita.

Existe una paradoja, si pensamos que la exageración de la verdad está frecuentemente relacionada con su falsificación. Pero hoy en día las nociones de originalidad y autenticidad se están reformulando constantemente, y acaso nadie esté en condiciones de decir nada verdaderamente original. Una opción válida puede ser la de exagerar lo original para que se vuelva a ver como algo nuevo. $\mathrm{Y}$ esto es perfectamente acorde con la condición y la sensibilidad posmoderna, en cuanto a que el melodrama opera con lo superficial, centrándose en la exageración.

Por otra parte, el melodrama supone una especie de espejo negativo, en el que lo melodramático es siempre el otro (los analfabetos, los sensibleros, los homosexuales...); todos los que no son de los nuestros. Resulta coherente pensar que, en efecto, existe una indeterminada pero inequívoca relación entre la recuperación del melodrama y la dimensión sobre-afectiva que alcanza cada vez más ámbitos de nuestra sociedad en este momento de sensibilidad hipermoderna, donde el "personismo" (en Yo y tú, objetos de lujo. El personismo: La primera revolución cultural del siglo XXI (2005) Vicente Verdú acuña este término) y el factor emocional no son ya separables tampoco de las narrativas artísticas fotográficas. Verdú apunta que, mientras en los períodos anteriores predominaba el interés por el ser humano, visto desde la mirada de un hombre, en la actualidad el interés gira más hacia la persona, desde una nueva óptica que podemos calificar de "femenina", centrada en la experiencia emocional: el llamado e-factor. (VERDÚ, 2005:58-59). En la época hipermoderna tiene lugar, en efecto, una sobre-sentimentalización del mundo, y 
resulta especialmente melodramática la paradoja de que cuanto más mejoran las condiciones materiales, más aumenta la sensación de una vida opresiva, caótica e insoportable que deriva en una profunda insatisfacción. En relación a estas cuestiones, es preciso comentar más en detalle la presencia unas prácticas artísticas (y fotográficas) que giran alrededor del melodrama.

En la actualidad, ante la gran variedad de propuestas al respecto, cabe plantearnos la pregunta: ¿Existe una estética definida del melodrama? Sin duda, podemos afirmar que existe un deseo generalizado de revelar secretos, de relatar, y de escapar de una denostada profundidad psicológica a través de la divulgación de pensamientos y sentimientos presuntamente íntimos. Recientemente se han aplicado parámetros melodramáticos en la configuración y la estructura del arte. Exposiciones multidisciplinares como "Melodrama", por ejemplo, son verdaderamente sintomáticas de este hecho.

Las obras aparecen contaminadas por elementos como teleseries de sobremesa, canciones pop, bisutería y artillería de bazar kitsch, películas de serie B, cómics, pintura de salón... Hacen gala de un lenguaje propio que predica el exceso sentimental y estético. Vemos que el arte no puede escapar de la influencia del melodrama, ni en los años 70, examinándolo con una mirada conceptual, ni en los 80, desenterrando su interés sociológico, ni en los 90, buscando el valor de las emociones. En la actualidad, ya bien entrados en el siglo XXI y con las exigencias de corrección política de la vida contemporánea, los artistas explotan algunas de las diferentes posibilidades del género del melodrama, demostrando además que, a pesar de que se sigue considerando un género de gusto pobre o anticuado, no podemos evitar sentirnos fascinados por él.

En el precedente que supone, por ejemplo, la exposición "Melodrama”, vemos que algunas de las obras utilizan específicamente el medio fotográfico, como la serie de 19 fotografías de Tracey Moffatt, titulada “Laudanum” (1999). Estas fotografías muestran un espacio doméstico victoriano (haciendo un guiño inequívoco a la tradición del género, ya que la época victoriana es la más frecuentemente asociada a la imaginación melodramática, en sus injusticias y logros, sus códigos y conflictos morales, etc.). El melodrama como producto

\footnotetext{
${ }^{1}$ La muestra "Melodrama", comisariada por Doreet LeVitte Harten fue expuesta en ARTIUM (Vitoria-Gasteiz, abril-septiembre 2002), el Centro José Guerrero (Granada, octubre 2002enero 2003), y en el MARCO (Vigo, Pontevedra, febrero-mayo 2003).
} 
victoriano, en este caso, se sitúa en el campo del espacio femenino, principalmente en la casa, y Moffatt adapta las sensibilidades de esta estética para transmitirlas a través de una narrativa subversiva y retorcida en estas fotografías. Las diferentes viñetas, que no parecen seguir un orden cronológico (ni lógico), responden a una confusión a caballo entre el ensueño y la pesadilla, como ordenadas bajo los efectos de un sueño de láudano. Este relato a base de imágenes, que carecen de lenguaje verbal, remite precisamente a lo reprimido, a su manifestación expresiva somática, a las historias sobre la "histeria femenina"... En cierto modo, la sugerente estrategia narrativa elegida por Moffatt aprovecha la forma en que el melodrama permite una vía de escape, una vía de expresión para lo reprimido emocional, social o político, lo que no puede ser dicho directamente de un modo "serio".

En general, "Melodrama" es una exposición paradigmática que se refiere principalmente a sí misma y que además se puede referir también a cualquier exposición, ya que, en palabras de la comisaria, "cada exposición es un acontecimiento melodramático, porque lo quiere todo, quiere explicar los usos y costumbres del mundo e insertar una idea de integridad en lo que parece una existencia sin sentido" (LEVITTE HARTEN, 2002: 120). Entre otras numerosas exposiciones que explotan y desarrollan los conceptos de lo melodramático, no podemos dejar de señalar las muestras colectivas "I Love You" (en el Centro Torrente Ballester, 2008), "Sur le Dandysme Aujourd'hui" (CGAC, 2011), "Modernizing Melodrama" (Carleton College Art Gallery, 2009), o "Acting Out" (Neuberger Museum of Art, comisariada por Kathleen Edwards en 2005, que posteriormente comentaremos).

\section{El melodrama fotodramático actual. Algunos casos particulares}

En la llamada "staged photography", una de las categorías ya habitualmente empleadas por la crítica en relación a la fotografía artística contemporánea, encontramos frecuentemente unos guiños más o menos deliberados con lo melodramático. Hay que aclarar, sin embargo, que no toda la fotografía escenificada o teatral es melodramática, ni todo melodrama fotografiado puede ser incluido en la categoría de "fotodrama" a la que nos referiremos: esta categoría básicamente utiliza el medio fotográfico de un modo 
construido/escenificado para transmitir contenidos e ideas que toman la forma de una narración o una historia, por breve o ambigua que ésta sea.

En el "fotodrama" se explotan recursos del cine, la pintura figurativa, el teatro, la novela o los propios usos tradicionales de la fotografía, pero el resultado final es una combinación imaginativa de hecho y ficción, una mezcla de algo fotografiado y de su significancia alegórica y psicológica. Los "fotodramas" asumen y desarrollan la idea de que toda imagen, toda representación, tiene un carácter construido. El medio fotográfico es explotado en su cualidad de perfecta similitud con la realidad, que parece prometer siempre una relación más fiel, descriptiva y denotativa con el referente. Este tipo de fotografía adquiere una posición de autonomía que supera las concepciones de lo icónico, lo sintáctico y lo representativo.

Las características del tableau fotográfico en la práctica contemporánea se refieren más directamente a la era pre-fotográfica de la pintura figurativa occidental. Como en las pinturas, el autor fotodramático elabora una imagen que es construida, a modo de ensamblajes de varias realidades, en las que se combinan elementos que derivan en varios grados de algo visto, y elementos esencialmente procedentes de la realidad interior del autor. Por otra parte, en la fotografía escenificada actual encontramos cómo los acuerdos tradicionales entre observador y objeto se ven destinados a una renegociación constante. Como constructos que son las fotografías escenificadas, imaginamos el modo en que se hizo cada fotografía, y para nosotros una parte significativa del significado de la imagen estará relacionado con el punto de vista que se nos ofrece, con los roles que se nos invita a desempeñar o proyectar ante cada escena.

En los tableaux fotodramáticos se desarrollan unas relaciones entre personajes en escena y espectador tratadas en la historia de pintura figurativa moderna, tema que recientemente ha vuelto a exponer Michael Fried, centrándose en la fotografía, en Why Photography Matters as Art as Never Before (2008). Desde los años 70, Michael Fried ha reconocido la importancia del tiempo para las artes plásticas (en especial la pintura) y ha desarrollado un discurso sobre modos de temporalidad en la representación pictórica figurativa, modos que serían independientes del la temporalidad literal o duración real del acto de 
contemplación o exhibición de la obra. Fried describe dos modalidades extremas de representación temporal en la pintura: la modalidad "durativa" ${ }^{2} \mathrm{y}$ la modalidad "instantánea" 3 . Las modalidades absorptiva-durativa e instantánea-dramática se insertan en el análisis historiográfico que hace Michael Fried sobre el origen del arte moderno, basada en la idea de la "tradición antiteatral" que surge en la Francia del siglo XVIII como reacción al "problema de la teatralidad": la obra artística cuyas figuras expliciten sus poses y su condición de artificio para complacer al espectador, o cuyo significado narrativo resulte confuso, es considerada "teatral". Estas ideas son ampliamente desarrolladas en El lugar del espectador. Estética y orígenes de la pintura moderna 4 (2000), a partir de las teorías de Diderot y de ejemplos de la pintura de la época. Posteriormente, Manet rompería con las convenciones del tableau antiteatral, optando por la representación de la instantaneidad en sí misma, afirmando la presencia física de la obra y del medio pictórico, como expone Fried en profundidad en Manet's Modernism (1996).

Las modalidades extremas de teatralidad (modalidad instantánea), ensimismamiento (modalidad durativa), e ilusoria participación incoativa (en un sentido de confrontación heredada desde Manet), aparecen en los fotodramas actuales en diferentes grados, e incluso se combinan frecuentemente entre sí. Cada una de ellas favorece la curiosidad del espectador acerca de la escena en la que virtualmente entra, en un figurado orden de participación (o no participación), viéndose obligado a resignificar lo que

\footnotetext{
2 La modalidad "durativa" significa que lo que aparece descrito en un cuadro tiene una duración literal, subsistiendo relativamente sin cambios, suspendido en el tiempo. Está ligada a una ilusión de duración y estabilidad de los objetos o acciones representados, e invita a una exploración y contemplación gradual. Esta modalidad está relacionada con temas absortivos, como los bodegones o los paisajes, o acciones mantenidas en el tiempo que sugieren la duración de lo representado. La estrategia de la modalidad absorptiva, además de proporcionar la ilusión de duración y permanencia de la acción en el tiempo, favorece la curiosidad del espectador acerca de la escena, en la que, de alguna manera, desea entrar silenciosamente para no interrumpir ese estado ensimismado.

3 La modalidad "instantánea" implica un espacio pictórico orientado hacia el espectador, y se caracteriza por la cualidad que Fried ha denominado "facingness" (podríamos traducirla como "cualidad de confrontación"); el espectador experimenta la ilusión de estar observando un instante que puede captar de un vistazo. A la modalidad instantánea le corresponden temas dramáticos, en los que la acción descrita no es repetitiva ni sostenida en el tiempo, sino que tiene una duración puntual, dando la sensación de instante único, de un momento significativo que se entiende dramáticamente. En la fotografía escenificada actual, encontramos obras que representan esta modalidad instantánea y temas dramáticos, expuestos justamente de un modo que hace que el espectador se sienta, de alguna manera, implicado en la escena.

4 La versión original de esta obra tiene como título Absorption and theatricality: Painting and beholder in the age of Diderot, $1^{\mathrm{a}}$ ed., Berkeley, University of California Press, 1980.
} 
acontece en la escena. El espectador, ya sea como participante de la escena, ya sea como testigo implícito o explícito, entra en un determinado campo de tensiones que responde a un juego ilusorio hábilmente planteado a través de la fotografía, que explota especialmente la cualidad de "momento compartido”, y entreteje cuestiones referentes a narratividad y espectáculo en una multitud de formas y estéticas (de las que lo melodramático se vale como modo de expresión).

A continuación vamos a prestar especial atención a las obras que, empleando estrategias del "staging” fotográfico (en cuanto a la construcción de escenas, al guión de tramas, a las poses de los actores/modelos), plantean temas y cuestiones que entroncan con estas cuestiones y relaciones de representación, y con una sensibilidad, unas temáticas, y una estética típicas del género del melodrama tradicional.

Con la entrada en la posmodernidad se hacen especialmente significativos los aportes de autores que, trabajando en el ámbito de la fotografía escenificada, juegan con códigos y estrategias del melodrama. Desde los comienzos de esta época encontramos un buen número de antecedentes inmediatos del melodrama fotodramático actual. Uno de estos precedentes está en el texto "Magnificent Obsession: An Introduction to the Work of Five Photographers"5, publicado en 1989. En él, Laura Mulvey comenta la obra de cinco fotógrafos (Mark Lewis, Geoff Miles, Oliver Richon, Mitra Tabrizian y Karen Knorr) que, según la autora, cuestionan y agitan las ideas preconcebidas de lo que debería ser una fotografía: la imagen fotográfica, como el cine, puede ser compuesta para escenificar ideas abstractas, el mundo interior del deseo o de lo imaginario. De la imagen fija se tienen expectativas de transparencia, pero hoy la fotografía se opone a esta perspectiva, perdiendo la anterior relación “de tú a tú" con la realidad.

Los artistas en "Magnificent Obsession" toman las ideas de "placer contemplativo" y de "realidad" como materiales para la ironía y el juego, echando mano de la yuxtaposición de imagen y palabra, de un modo flexible, a veces oblicuo. Mulvey señala que la estética negativa desafía la ortodoxia crítica,

5 El texto de Laura Mulvey "Magnificent Obsession: Introducción a la obra de cinco fotógrafos" (1989) está publicado en RIBALTA, Jorge (ed.): Efecto Real. Debates posmodernos sobre fotografía (2004). Barcelona: Gustavo Gili, col. FotoGGrafía (pp. 216-230). 
construyendo alternativas y atrayendo la imaginación del espectador a la vez que se construye el discurso. El espectador se sorprende implicado en la tarea de descifrar la imagen y crear el significado del texto: todas las series fotográficas que forman parte de la muestra giran, de alguna manera, en torno a pistas. Las imágenes hacen que el monólogo interior del espectador se convierta en una interpretación verbal interna: las palabras no explican la imagen, sino que añaden otro nivel al discurso.
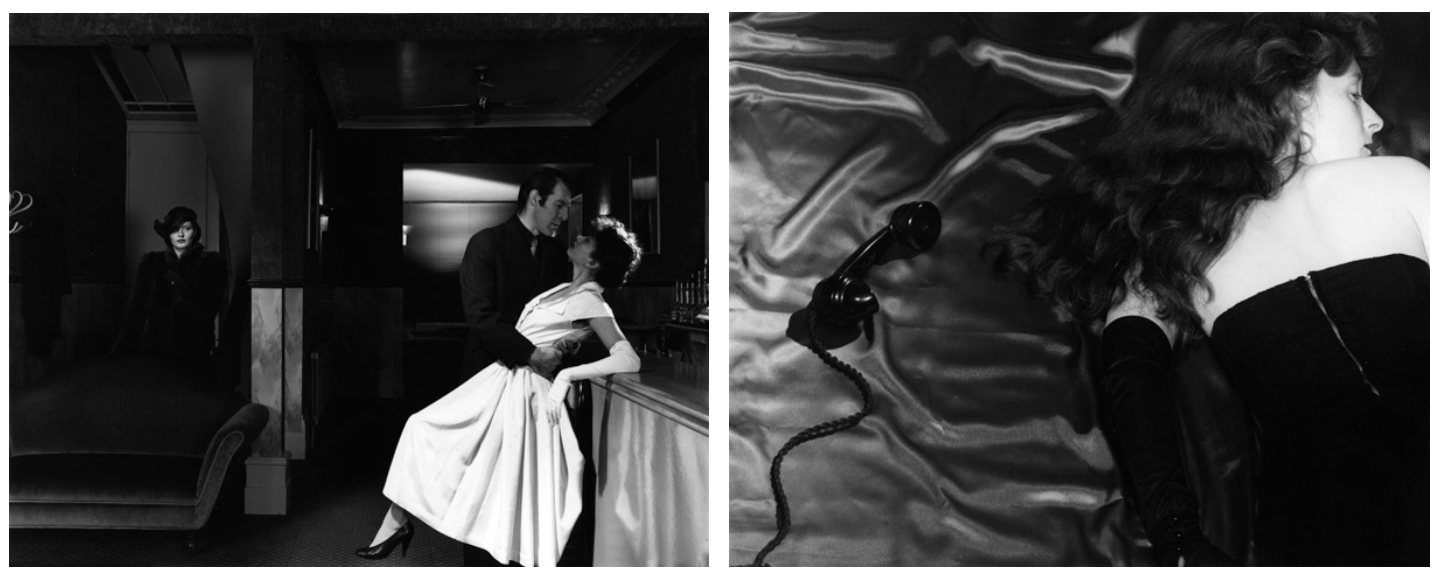

Mitra Tabrizian: Imágenes de la serie "Correct Distance" (1985-1986)

El título de la exposición ("Magnificent Obsession”), tomado de la película homónima (1954) de Douglas Sirk, remite al género del melodrama, explotando la capacidad narrativa de la fotografía. En la exposición tal vez no haya una línea argumental precisa, pero sí unos intereses y preocupaciones culturales compartidos. En las obras expuestas tenemos que "leer" la puesta en escena a través de la representación visual del significado, que es siempre construido y no-naturalista. Estas imágenes no representan el mundo, sino que revelan los síntomas del material reprimido en el inconsciente o en la ideología, y las "realidades" que se presentan en las fotografías no son visibles a simple vista ni tampoco visibles para el objetivo. Podemos decir que lo que hacen estas obras es materializar mundos culturales, abiertos al deseo del espectador.

En esta muestra destacan las fotografías de Mitra Tabrizian (artista de origen iraní que vive y trabaja en Londres). Las imágenes de la serie "Correct Distance" (1985-1986) evocan códigos y estéticas del film noir, describiendo escenas que nos invitan a entrar en un mundo de deseos inconfesados (o inconfesables) y reprimidos. Estas fotografías tienen una importante carga de glamour psicoanalítico, y explotan la figura de la femme fatale en relación a las fantasías 
de la mujer actual. Esto resulta especialmente interesante, si tenemos en cuenta que Tabrizian procede de una cultura iconoclasta. Las imágenes de "Correct Distance" contienen siempre espacios ficticios conflictivos, y permiten al espectador una distancia de las formas dominantes del voyeurismo y exhibicionismo, tal y como los encontramos en una gran variedad de códigos visuales y discursos. Su caso es paradigmático en cuanto a la relación de lo fotográfico, lo cinemático (la artista es, además de fotógrafa, una impecable directora de cine) y lo melodramático, y las imágenes han sido exquisitamente escenificadas (verdaderos triunfos de la mise-en-scene). Pero también son, en un sentido más psicoanalítico, “escenas” en las que las fuerzas de la fantasía, el deseo y la violencia, obedeciendo a una lógica alternativa, emergen de la superficie de la imagen y funcionan libremente operando a modo de narrativas bellamente condensadas.

También en la década de los 80 Eileen Cowin echa mano de la estética de la teleserie o sit-com para ofrecer unas escenas protagonizadas por personajes que podrían pertenecer a cualquier familia media americana, congelando instantáneas como si de un fotograma se tratase. En el caso de "Untitled (Frame and Red Rose)" (1983), perteneciente a la serie "Family Docudrama”, la escena está protagonizada por varias personas enfrascadas en actividades que parecen independientes unas de otras, en una relación oblicua cercana a las nociones de pose. En una pareja de pie, besándose, inexplicablemen te aislada por un marco suspendido en el aire, un hombre entrega una rosa a otra mujer sentada en un sillón, mientras unos muchachos

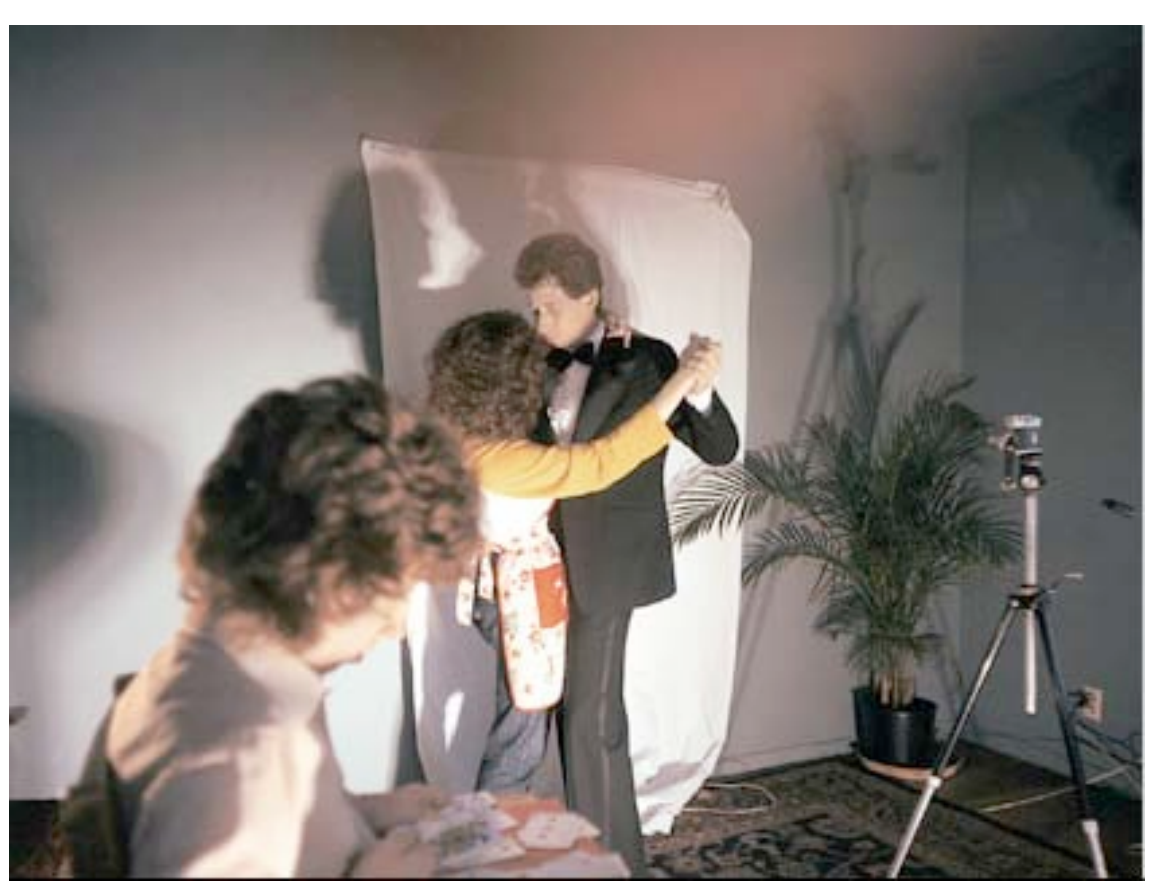


juegan en el suelo. La situación, absurda, supone una especie de narrativa miscelánea que finge presentar situaciones singulares. Pero también es una escena compleja, que excita nuestro apetito interpretativo a través de la estructura de las posturas, los contactos visuales, y nos hace pensar en que estos personajes cliché tal vez son alegorías que exploran las relaciones sociales de los estereotipos que conforman nuestro ámbito cultural (hoy en día, condicionado en gran medida por los mass-media, y en especial por la televisión...).

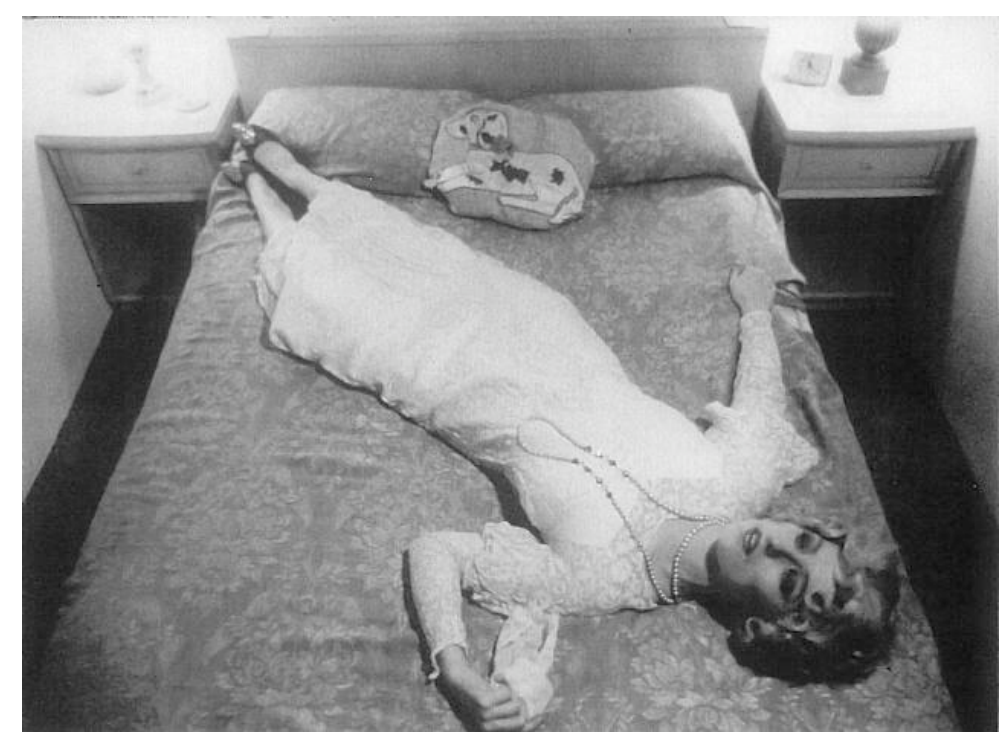

Cindy Sherman: "Untitled Film Still \#11" (1978)

Cindy Sherman es otro caso paradigmático de los antecedentes inmediatos de la práctica del melodrama fotodramático actual. Los "Untitled Film Stills" de los años 70 son un claro homenaje a toda una estética y a un género cinematográfico en el que personajes siempre femeninos (y siempre encarnados por la misma autora) se enfrentan a situaciones imprecisas y de una latente tensión emocional en parte desencadenada por los roles que cada una de las mujeres descritas se ve condenada a desempeñar.

Por su parte, en "Belgravia" (1979-1980) Karen Knorr nos presenta un conjunto de retratos de diferentes personas en entornos domésticos, en sus mansiones del elegante barrio londinense que da título a esta serie fotográfica (una de las primeras de la autora). Cada una de las imágenes va acompañada por un breve texto, cuya tipografía evoca un libro de texto escolar sobre las ideas y actitudes de la clase alta construidas a partir de conversaciones. Para destacar el carácter artificial del texto, compuesto bajo la imagen fotográfica, determinadas palabras claves aparecen escritas en mayúsculas (como por ejemplo "Privilegio" en "No 
hay nada malo con el Privilegio, siempre que estés dispuesto a pagar por él”). Al igual que los textos, las poses de los personajes son artificiales, estáticas y afectadas, y describen a unos sujetos convertidos en objetos de su propia sociedad. Karen Knorr profundiza en esta serie (al igual que hace con otras series de la misma época, de sus inicios, como “Gentlemen”) sobre la relación del hombre con la sociedad, su cultura y su patrimonio en Occidente. Y en este caso, lo hace en clave melodramática, a través de la exposición estereotipos y de valores que hoy nos parecen obsoletos y snob, y de la presentación de entornos domésticos donde todo se muestra armónico y lujoso, mientras nos deja entrever la existencia de prejuicios infundados socialmente y los conflictos interiores latentes en los individuos de esa clase social.

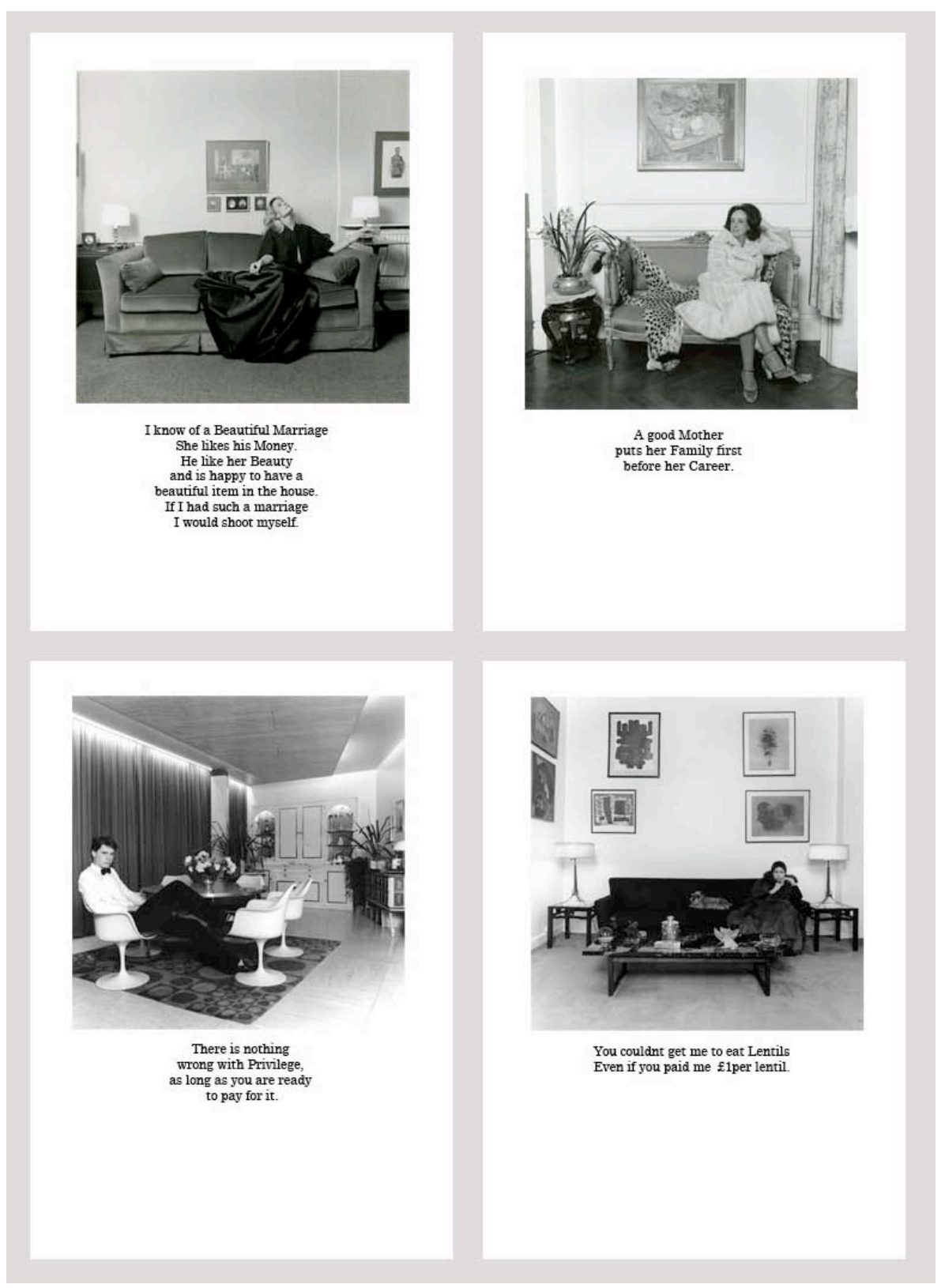

Karen Knorr: Fotografías de la serie "Belgravia" (1979-1980) 
El trabajo de la artista norteamericana Tina Barney se centra también en un pequeño microcosmos social, el de su propia familia (ella pertenece a una familia de clase alta de la élite de Long Island), que de este modo se convierte en un escenario de doble sentido para la autora: un lugar de desenvolvimiento personal e introspección psicológica. Sus imágenes constituyen una valiosa fuente sobre la vida privada y el entorno de ellos, deteniendo su mirada narrativa en las acciones y situaciones cotidianas de estos personajes. Todos pertenecen a la "aristocracia blanca, anglosajona y protestante" de Estados Unidos (WASP).

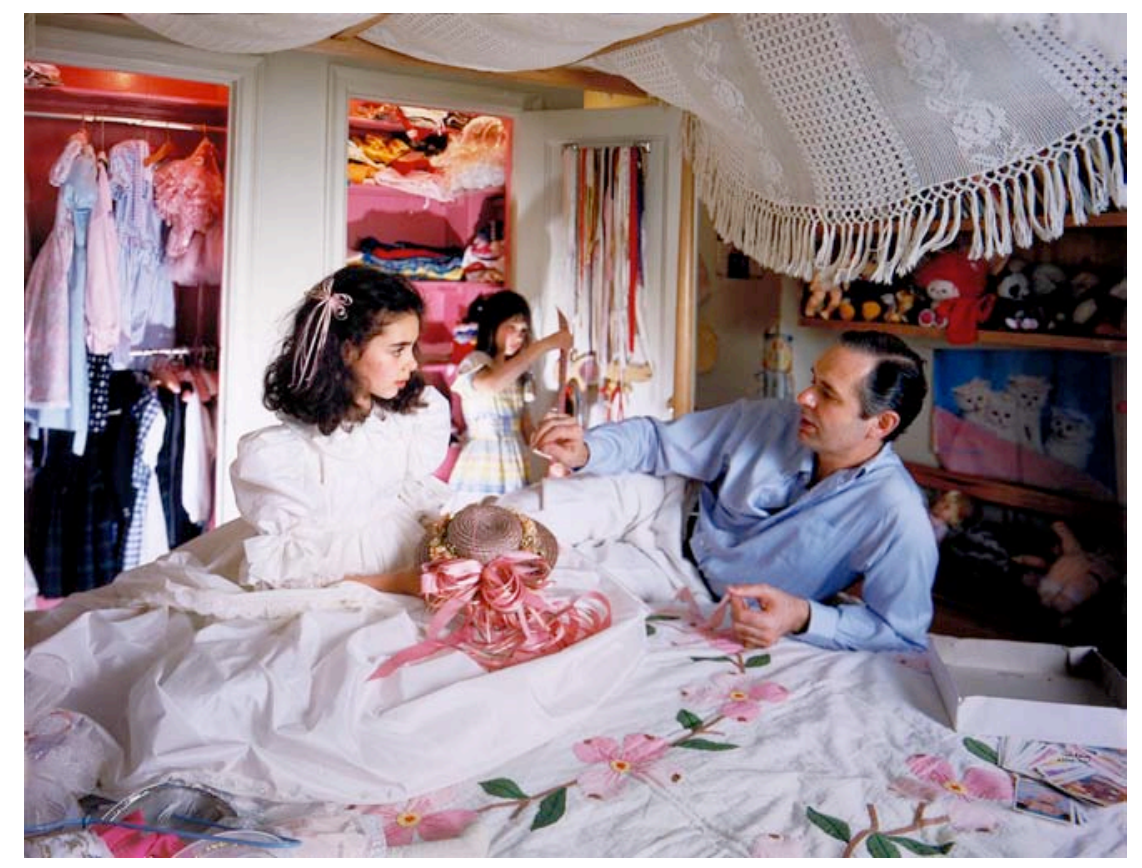

Tina Barney: "Marina's Room" (1987)

A caballo entre el documento y la ficción, las escenas que Barney nos presenta juegan con la artificialidad y el despliegue de pequeñas representaciones y teatros de la vida cotidiana de estos personajes que tan bien conoce, y cuya apariencia resulta tan similar a la de los personajes de un melodrama de Douglas Sirk, o de exitosas series televisivas norteamericanas como "Dallas" o "Falcon Crest". Igualmente, los elegantes y profusamente decorados escenarios, el gran formato de las fotografías y sus impecables y brillantes colores aportan una idea de vividez y realismo que nos permiten acceder virtualmente a este mundo de glamour irresistible. El resultado es un "teatro de la conducta" o "teatro de los modales", como la propia fotógrafa define su trabajo: un álbum de 
familia que es sinécdoque de toda una clase social, un ámbito confortable que sin embargo deja entrever una cierta desazón a través de las expresiones de los rostros de sus protagonistas, que al final siempre resultan ser, como en los mejores melodramas, unos "pobres niños ricos".

Volvemos al caso de Tracey Moffatt, una artista cuyo trabajo está ligado a la imaginación melodramática por antonomasia, tanto en su faceta de cineasta como en la de fotógrafa. Su proyecto está regido, en gran medida, por una concepción de lo melodramático como algo que construye realidades inauténticas e indeterminadas. La artista utiliza medios no verbales de expresión, unas puestas en escena y unos gestos en los personajes que sin embargo, transmiten un intenso significado narrativo y emocional. Series como "Something More" demuestran que la estética de lo mudo sirve para expresar experiencias traumáticas impronunciables. También encontramos en su serie "Scarred for Life" un conjunto de relatos de tono pseudo-sentimental, en combinaciones de imagen y texto en las que parecen combinarse sentimientos contrapuestos de recuerdos, frustraciones, rabia contenida y victimismo. La estética está inspirada en fotografías de los años 50 o 60 (como sacadas de la revista "Life"), y en cada historia se inscribe un conflicto doméstico, familiar, existencial. Esta serie está relacionada con la labor que el melodrama permite en cuanto a la exposición de asuntos de violencia y opresión en el ámbito familiar, proponiendo ese "retorno de lo reprimido" y la revelación de fuerzas ocultas que remiten a lo siniestro freudiano, provocando asimismo sentimientos complejos en el espectador.

Además, encontramos en la obra de Moffatt una consistente ambigüedad en relación a los imperativos morales del melodrama. Al contrario que en los melodramas teatrales y literarios tradicionales, que dividían el mundo en dos cortes claros y binarios (bien/mal), los relatos fotográficos de esta autora suponen una ambigüedad moral que reta al espectador a realizar sus propios juicios en lugar de confiar automáticamente en la moral preestablecida y en las premisas políticas.

Ya en el contexto más reciente, una exposición que hemos de destacar por su significancia específica en la tendencia melodramática dentro del campo de lo fotográfico es la muestra titulada "Acting Out: The Invented Melodrama in 
Contemporary Photography"6, en la que se muestran trabajos de 13 artistas representativos de esta tendencia melodramática en la fotografía escenificada. Comisariada por Kathleen A. Edwards, la exposición presenta 31 trabajos de Tina Barney, Gregory Crewdson, Philip-Lorca DiCorcia, Anna Gaskell, Tom Hunter, Simen Johan, Justine Kurland, Laura Letinsky, Sharon Lockhart, Adi Nes, Cindy Sherman, Yinka Shonibare, Janaina Tschape y Jeff Wall. Todos estos artistas, en sus diferentes enfoques, planean cuidadosamente la fabricación de sus fotografías, operando como directores de cine y colaborando casi siempre con un equipo de actores y técnicos. Dentro de estas fabricaciones, las fotografías presentadas tienen un impacto significativo, debido en gran medida a la presencia del melodrama, un aspecto narrativo penetrante y que frecuentemente pasa desapercibido a la vez. A través de sus elementos, la exposición examina la presencia del melodrama en la fotografía artística contemporánea, abriendo un debate acerca del melodrama como un sistema estético de percepción derivado del desarrollo de la sociedad moderna en Europa occidental y Estados Unidos. Considerando el melodrama como un sistema con una larga tradición en el dar sentido a la experiencia, esta exposición pretende analizar cómo funciona el cuerpo expresionista que apela a las emociones del espectador, ofreciendo formas de reconocer y liberar sentimientos.

Podemos comprobar que las fotografías escenificadas en la actualidad exploran y explotan características del melodrama fabricado, caracterizado por el pathos, la emoción desmesurada, la polarización moral, las narraciones o estructuras no tradicionales y los eventos extraordinarios. Los artistas que exploran estas cuestiones en sus obras investigan el melodrama como un sistema estético de representación influenciado por la literatura, el teatro, el cine, los fotogramas y la fotografía histórica.

El uso y abuso de colores brillantes y saturados es una de las señas de identidad de las fotografías del argentino Marcos López. Encontramos en sus imágenes una iconografía pop, casi delirante, que ha sido calificada como "pop latino". El artista emplea el recurso de la ironía como una estrategia para distanciarse de

6 "Acting Out: The Invented Melodrama in Contemporary Photography" fue una exposición comisariada por Kathleen A. Edwards que tuvo lugar en el Neuberger Museum of Art (Purchase, Nueva York, EEUU), del 5 de septiembre al 31 de diciembre de 2005. 
temas dolorosos relativos a diversas situaciones de la realidad política y social de Argentina, de un modo un poco escéptico, un poco desmitificador. Con influencias reconocibles de diversos campos, como el cómic, la publicidad, o el muralismo mejicano, Marcos López nos ofrece una nueva visión de algunos estereotipos y tópicos latinoamericanos (que a veces tienden a mostrar la miseria de sus gentes), exagerándolos y convirtiéndolos en imágenes atractivas y alegres, acentuando así sus males más todavía.

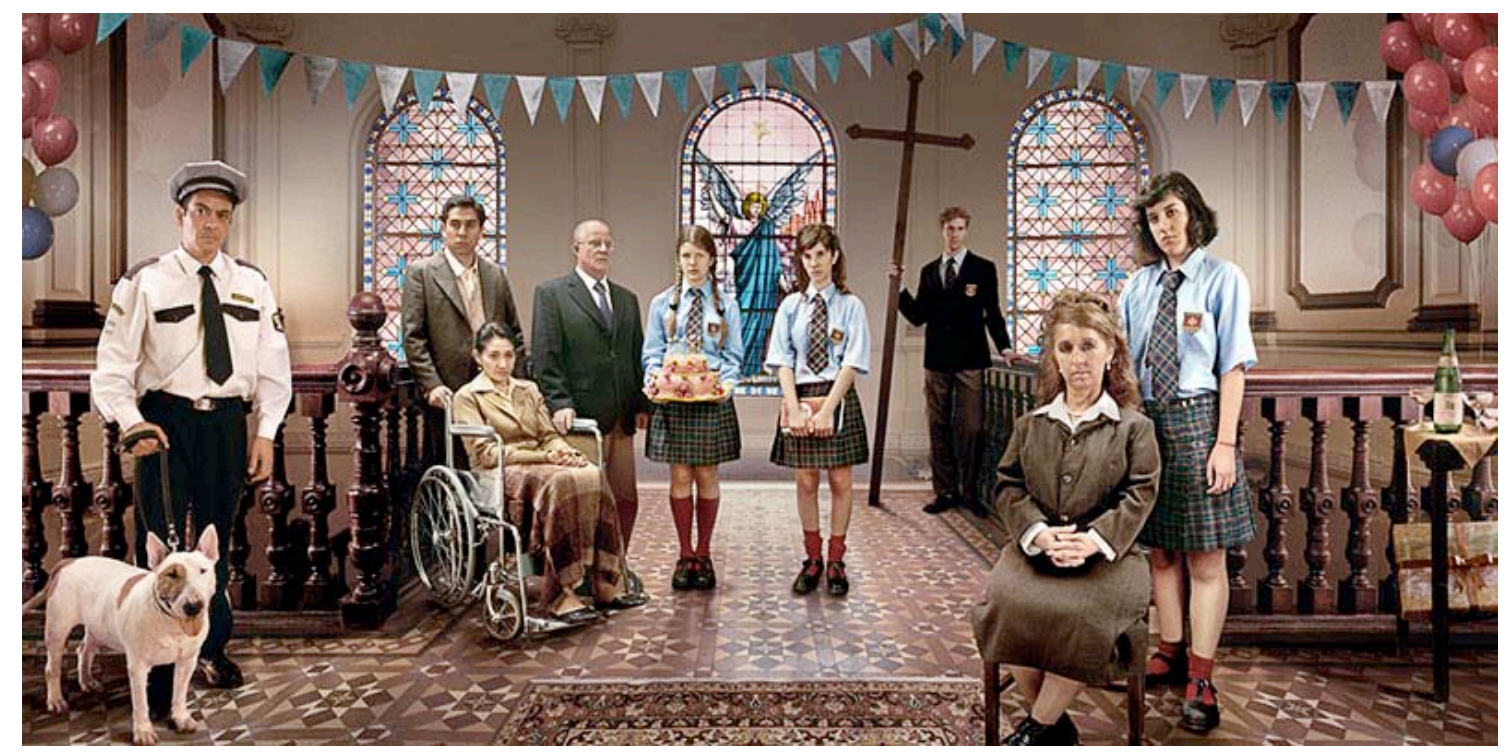

Marcos López: "El cumpleaños de la directora” (2008)

El tono de algunas de las imágenes de López es especialmente melodramático, en este caso en un sentido cercano a la telenovela latinoamericana. Esto lo podemos comprobar en obras de la serie "Surrealismo Criollo", como por ejemplo en "El cumpleaños de la directora" (2008), donde el artista pone de manifiesto la "mortal rigidez de las instituciones", frecuentemente de estricta moral católica, que genera conflictos en las relaciones personales y sociales. Mediante una estética de poses forzadas, colores exagerados y elementos y personajes locales reconocibles, propone una especie de estudio sociológico. El artista realiza una reflexión en clave de humor en relación a la identidad latinoamericana a través de ciertos mitos y lugares comunes, y también una reflexión acerca de la mirada globalizadora del consumismo americano y al desmesurado deseo de apariencia en la clase media argentina.

Marcos López ha fijado una iconografía propia y mestiza que alía lo convencional y lo diferente, el espectáculo y la tragedia, la autenticidad y el 
estereotipo, componentes extraídos del ámbito de los medios de comunicación propios del melodrama, en el que la televisión y las telenovelas, las historietas y sus superhéroes, el cine y las estrellas, dibujan una irrealidad cada vez más engañosa, menos comunicativa, más enajenante. López refunda este universo y, a partir de una puesta en escena personal caracterizada por la estridencia cromática, el efectismo y la afectación en la concepción de sus escenografías, la asimilación de los elementos del kitsch urbano, la precisión y el equilibrio en la estructura formal de la composición, consigue introducir al espectador en un proceso de identificación con algunos de los ámbitos más privados del individuo, que configura su propia existencia y que traduce el desconcierto, el escepticismo y una sensación de descontextualización.

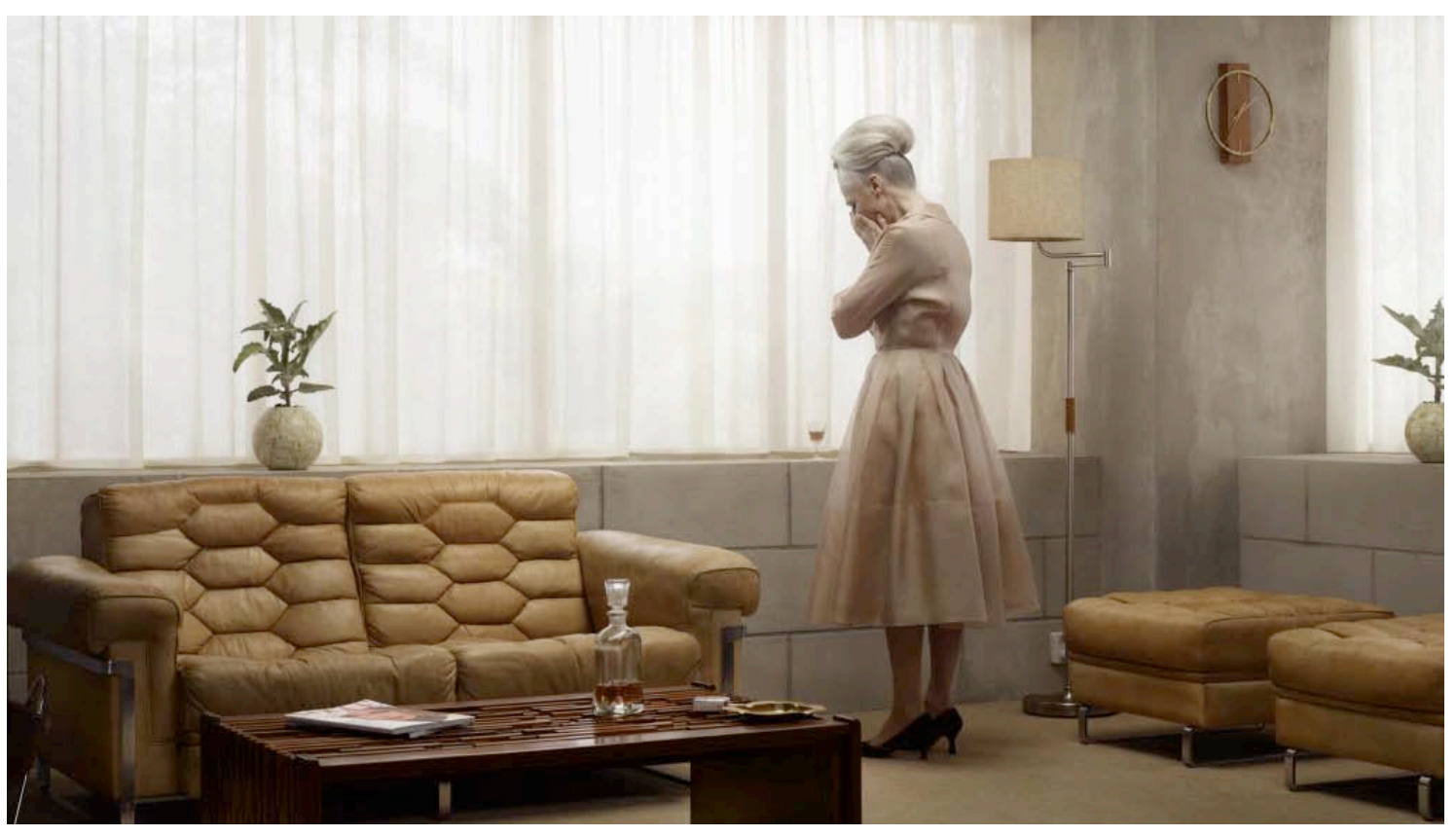

Erwin Olaf: “Grace”, de la serie “Grief” (2007)

El proyecto fotográfico de Erwin Olaf aborda temas como el sexo, el deseo, la belleza y la violencia de un modo frecuentemente directo y explícito, realizando una crítica incisiva de la hipocresía social, la doble moral o los tabúes de la sociedad de consumo contemporánea, cuestionando, a su vez, las nociones relacionadas con la belleza y su valor. En series recientes como "Paradise" (2001) o "Separation" (2003) aparece un cierto tono dominante de pesimismo y melancolía. Pero especialmente hemos de reparar en una de sus últimas series, titulada "Grief" (2007), que supone un punto de inflexión en tanto que por primera vez no busca un aire de erotismo ni referencias a la sexualidad de 
ningún tipo: las fotografías pertenecientes a esta serie conjugan una sofisticada combinación de arte, moda y emoción, en un intento de devolver el glamour a la sensación de depresión personal. Figuras solitarias conscientes de su propia belleza, vestidas con ropas elegantes y pulcras esperan en habitaciones igualmente impolutas y perfectas, mirando fijamente al suelo, o a través de la ventana, o enjuagándose las lágrimas de sus ojos. Incluso la armoniosa paleta de colores suaves sugiere una impecable melancolía. Erwin Olaf nos ofrece la desgracia o la miseria de estos personajes (algo que nunca seremos capaces de determinar realmente) en su forma más exquisita, sin que aparezca un solo kleenex arrugado en escena, sin ningún detalle que empañe la cualidad brillo de estos sentimientos sublimados.

Inevitablemente, estas fotografías nos devuelven a las pinturas de Edward Hopper, y también a otro tipo de referencias visuales tan influyentes como los melodramas de Douglas Sirk o John Stahl. Las imágenes despliegan una especie de serenidad pasiva, casi resignada, y una atmósfera introspectiva que nos habla de soledad e incomunicación. Tal vez los personajes de estos cuadros no mantienen relación alguna entre sí y estén realmente aislados; la aparente felicidad prometida por esos entornos agradables y diáfanos no impide una sensación de abandono y de silencioso desencanto. El artista, sin embargo, no deja de realizar un comentario crítico la sociedad y de sus valores predominantes, en esta ocasión sobre la falacia de las apariencias, sobre los entornos familiares que de repente se vuelven extraños y desoladores, sobre las tormentas interiores que tienen lugar silenciosamente en superficies apacibles y en principio tan confortables como estos hogares de diseño. El título de la serie apela a un sentimiento universal de pérdida y de tristeza, y ese es precisamente el denominador común de las situaciones individuales que se presentan. Como espectadores, podemos proyectar nuestra propia sensación en la imagen y darle un contenido específico, puntual.

También en su proyecto "Royal Blood" (2000), Erwin Olaf realiza una serie de retratos imaginarios de algunas víctimas violentas de la historia, y estos personajes son virtualmente retratados justo unos instantes después de su muerte, posando hacia la cámara como verdaderos modelos. Estos simulacros de personajes históricos entre los que encontramos a Julio César, Ludwig de 
Baviera, María Antonieta, la zarina Alexandra o la emperatriz Sissi, y contemporáneos como Jackie Kennedy-Onassis o Lady Di, encarnan el gusto por las tragedias, el morbo sensacionalista y el melodrama en la sociedad actual. Todas las imágenes de esta serie presentan una apariencia casi ideal (tonos platino en el cabello, peinados perfectos, adornos de perlas y oro blanco, indumentarias impecables...), potenciada por la uniformidad nacarada aportada por Photoshop y una iluminación que aplana los volúmenes. Pero esta frialdad cadavérica se ve manchada por la aplicación de heridas "reales" (en el doble sentido del término en español): la sangre "real" de los protagonistas se ha conseguido montando digitalmente imágenes reales de sangre de una carnicería. En este sentido, Olaf opera del mismo modo que Stanley Kubrick (por cierto, también excelente fotógrafo) en las películas de "La naranja mecánica" (1971) o "El resplandor" (1980): la geometría y la perfección volumétrica de la arquitectura racionalista, se convierten en escenario o soporte de la violencia más terrible.
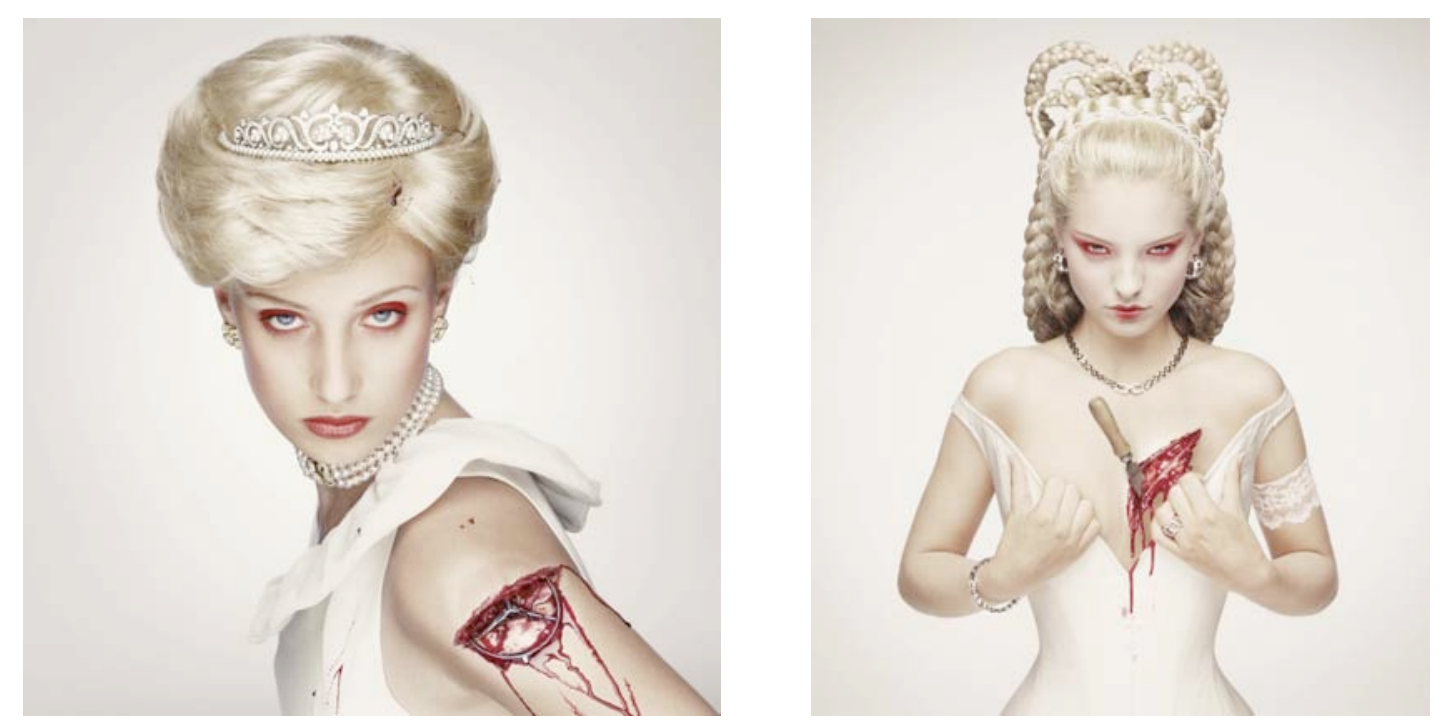

Erwin Olaf: "Di 1997", de la serie "Royal Blood" (200o)

Erwin Olaf: "Sissi 1898”, de la serie "Royal Blood" (200o)

Aunque el artista inglés de origen africano Yinka Shonibare trabaja con diferentes proyectos de diferentes disciplinas (escultura, vídeo, instalación..), nos interesa en relación al tema del melodrama por la propuesta de su serie fotográfica "Diary of a Victorian Dandy" (1998). En general, sus trabajos están realizados en una clave de humor en relación a las expectaciones culturales de la modernidad y la comprensión de las identidades culturales. 


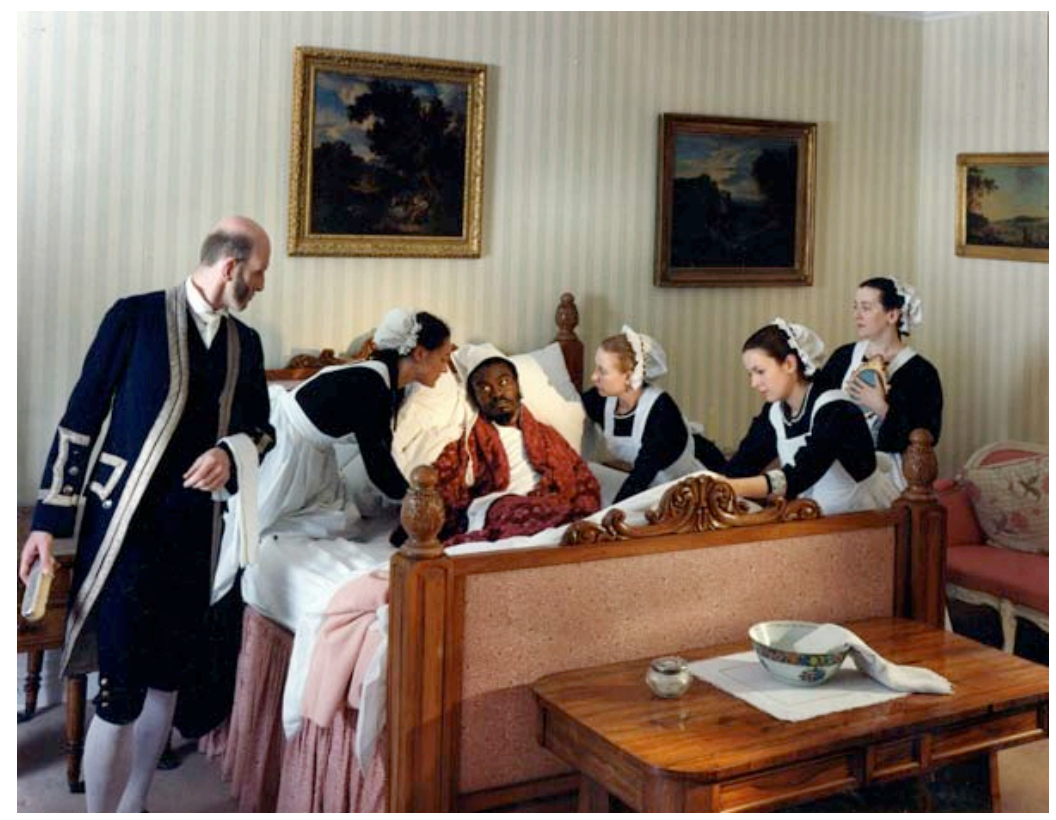

Yinka Shonibare: Fotografía perteneciente a la serie "Diary of a Victorian Dandy" (1998)

Shonibare realiza una seductora pero afilada crítica a los imperios colonialistas entrando en su propio juego, partiendo de una estética propia del estilo de vida europeo en la época colonial. En "Diary of a Victorian Dandy" intenta desestabilizar las asociaciones familiares sobre los nexos de raza, clase y autoridad, a través de disposiciones altamente melodramáticas, teatrales y sofisticadas. En estas escenas, siempre aparece una serie de sirvientes y mayordomos, secretarios o doncellas alrededor del personaje central de Shonibare (un hombre de raza negra que encarna el centro de actividad y atención en cada ocasión). Así, Shonibare aparece orgulloso recibiendo toda clase de atenciones, cuidados y adulaciones en escenas que se despliegan en elegantes estancias domésticas (sus aposentos, el despacho, la sala de billar, salones, etc.), mientras asume el papel de poder. De este modo, su figura sustituye a la del caballero victoriano que esperaríamos ver en esas situaciones, rompiendo de un modo provocativo con la imagen tradicional de la sociedad a la que hace referencia.

El fotógrafo turco Nazif Topçuoglu trabaja también en el terreno de la fotografía construida, con un proyecto en el predomina el protagonismo de personajes juveniles femeninos posando en escenarios de interior, frecuentemente implicados en acciones y roles simbólicos. Este artista utiliza de un modo recurrente entornos privados burgueses en relación a la psicología femenina y sus implicaciones sociales, algunos de los elementos preferidos del melodrama. 
Con referencias diversas a la pintura (en el cromatismo cuidado, la iluminación efectista, el encuadre, el sentido compositivo y la profusión de detalles) y al teatro (con un énfasis en el gesto melodramático), las adolescentes protagonistas interactúan en unas escenas en las que nada es casual.

Algunos de los trabajos más recientes de Topçuoglu tienen lugar en bibliotecas de un estilo anticuado, que recuerda a estancias victorianas inglesas. En estas estancias las chicas se ven envueltas en situaciones y acciones muy estilizadas, pero en las que sin embargo suele haber siempre algún tipo de violencia, ya sea ésta más física (en forma de luchas cuerpo a cuerpo o de arrojamiento de libros) o más latente. Hay una cierta reflexión social en las fotografías de este artista, teniendo en cuenta que éste procede de Turquía, un país donde el índice de analfabetismo es todavía elevado, especialmente entre las mujeres. Los libros son un elemento recurrente en la obra de Topçuoglu: no son solamente un símbolo de conocimiento, sino que además son herramientas de fortalecimiento para la mujer. Sin embargo, en las fotografías de Topçuoglu no es tan interesante esta reivindicación como la ambigüedad narrativa que encierran. Encontramos un aire de innegable erotismo, un tono relacionado con la sexualidad femenina y probablemente con una tendencia de sumisión. Y a la vez, las muchachas son mostradas en actitudes de curiosidad, de poder, e incluso en posiciones agresivas que ponen en cuestión las definiciones estereotipadas de la joven femineidad. Así, también surge un lado siniestro y desestructurante en las imágenes, en tanto que muestran que las mujeres también establecen entre ellas relaciones de violencia, incluyendo la física.

Topçuoglu apuesta por una sensibilidad román-tica casi decimonónica y por unas puestas en escena clásicas (digamos, pasadas de moda). Sin embargo, los subtextos de sus fotografías permane-cen esencialmente con-temporáneos, tocando te-mas que van desde las políticas de los géneros hasta cuestiones de voyeurismo y deseo asociados a la mirada masculina. 


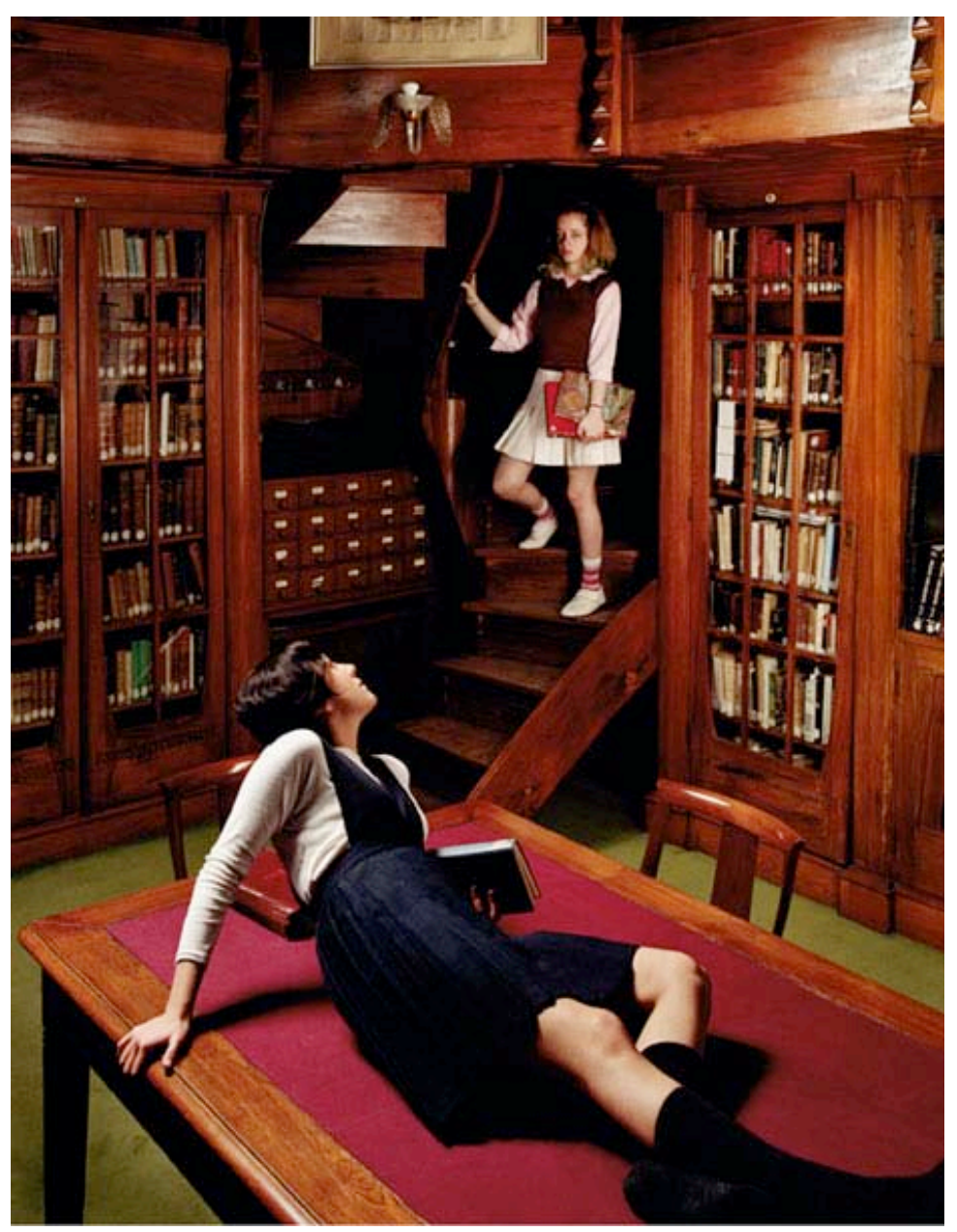

Nazif Topçuoglu: “Chance Encounter”, de la serie "Recent Readers”(2003)

Por último, además de los artistas y las obras comentadas anteriormente, no podemos dejar de señalar que existe una verdadera diversidad de artistas que emplean la fotografía escenificada siguiendo diferentes pautas melodramáticas en cuanto a los temas, disposiciones, estrategias, gestos, tonos... Entre ellos, no debemos dejar de citar a algunos nombres como Duane Michals, Gregory Crewdson, Holly Andres, David LaChapelle, Darren Sylvester, Anthony Goicolea, Anna Gaskell, Tom Hunter, Ixone Sádaba, Jeff Wall, Sam TaylorWood, David Hilliard, Florence Paradeis o Johan Wilner. 


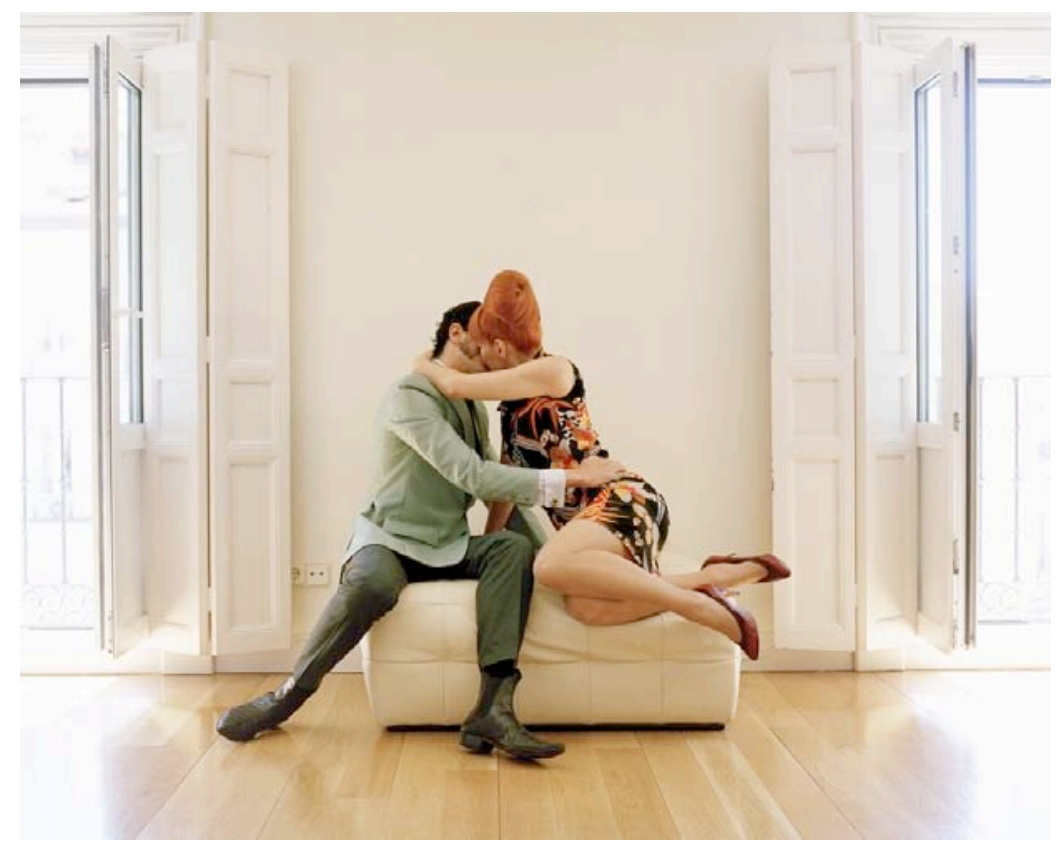

Marta Soul: Fotografía de la serie "Idilios" (2010)

En conclusión, podemos distinguir el efecto de lo melodramático en la producción artística-fotográfica actual, tanto en un nivel visual como en un nivel conceptual o temático. Lo melodramático, como modo de ver el mundo, relacionado con la primacía de los sentimientos y con la exposición de conflictos psíquico-sociales, se convierte en una tendencia privilegiada en la época hipermoderna y encuentra el la fotografía construida un aliado ideal: la expresión de lo personal como social, el valor crítico y hasta perverso de lo aparentemente convencional, el enfoque "femenino", y la simbolización de identidades, relaciones y construcciones ideológicas y culturales se articulan en forma de escenificaciones fotográficas que tratan unos determinados conflictos contemporáneos.

Como en el melodrama tradicional, en el que se enmascara la superficie de la realidad, la fotografía funcionan como "máscara" para (de una manera codificada) representar y criticar diversos aspectos de la existencia cotidiana. La teatralidad deliberada, el dramatismo y la importancia comunicativa y simbólica de los gestos en las escenificaciones, la hipérbole de lo cotidiano, el gusto por las tragedias y el morbo sensacionalista, el protagonismo frecuente de lo banal y lo aparentemente superficial en las fotografías actuales nos remite, sin duda, a una sensibilidad melodramática. De alguna manera, esta tendencia subraya la sensación hipermoderna de que cuanto más aumentan las condiciones 
materiales y de bienestar, más aumenta la sensación de una vida opresiva y de insatisfacción; la aparente felicidad prometida por todos los nuevos entornos materiales (e ideológicos) a la carta no evita una sensación inconsolable de incertidumbre y de desencanto. En este panorama el melodrama funciona como un sistema estético mediante el cual percibimos y teatralizamos la realidad.

El exceso sentimental y estético característicos del melodrama encuentran, por tanto, un formato idóneo en la fotografía escenificada actual, que funciona como una vía de expresión calculada de lo reprimido (tanto en el ámbito social, político o emocional), y de lo que no puede ser enunciado de un modo "serio". Lo melodramático se pone también de manifiesto en una tendencia a la producción de realidades inauténticas, enfatizando el carácter construido de la representación visual de significados. Sin embargo, al contrario de lo que suele suceder en el melodrama tradicional, no encontramos en los fotodramas actuales posiciones claras o maniqueas, sino una deliberada ambigüedad (narrativa, moral) que nos desafía, como espectadores, a aportar nuestros propios juicios o valoraciones.

\section{Referencias Bibliográficas}

BAQUÉ, Dominique (2003). La fotografía plástica. Un arte paradójico. Barcelona: Gustavo Gili, col. FotoGGrafía.

BREA, José Luis (1991). Nuevas estrategias alegóricas. Madrid: Tecnos, col. Metrópolis.

BROOKS, Peter (1976). The melodramatic imagination: Balzac, Henry James, melodrama, and the mode of excess. New Haven: Yale University Press.

CATÁlOGO (1996). Cindy Sherman. Madrid: Museo Nacional Centro de Arte Reina Sofía.

CATÁlogO (2002). Melodrama. Comisaria Doreet Levitte Harten. VitoriaGasteiz: Artium / Vigo Marco / Centro José Guerrero, Granada.

CATÁLOGO (2004). Mitra Tabrizian: Beyond the Limits. Londres: Steidl.

CATÁlogo (2008). Erwin Olaf. Photographs by Erwin Olaf. New York: Aperture Foundation.

COLEMAN, A.D. (1979). "The directorial mode", en Light Readings: A Photography Critic's Writings, 1968-1978. Oxford and New York: University Press.

COTTON, Charlotte (2004). The Photography as Contemporary Art. Londres: Thames and Hudson, col. World of Art. 
EDWARDS, Kathleen A. (2006). Acting Out: Invented Melodrama in Contemporary Photography. Iowa: University of Iowa Press.

FELIX, Z./SCHWANDER, M. (ed) (1995). Cindy Sherman. Photographic Work 1975-1995. Munich: Schirmer Art Books.

FOSTER, Hal (ed) (1983). The Anti-Aesthetic; Essays on Postmodern Culture. Port Townsend, Washington: Bay Press.

FRIED, Michael (2000). El lugar del espectador: estética y orígenes de la pintura moderna. Madrid: Antonio Machado Libros.

FRIED, Michael (1996). Manet's Modernism, or The Face of Painting in the 186os. Chicago: University of Chicago Press.

FRIED, Michael (2008). Why Photography Matters as Art as Never Before. New Haven: Yale University Press.

GLEDHILL, Christine (1987). Home is where the Heart is: Studies in melodrama and the women's film. Londres: British Film Institute.

HOY, Anne H. (1987). Fabrications: Staged, Altered and Appropiated Photographs. New York: Abbeville Press.

KÖHLER, M. (ed) (2005). Constructed Realities: The Art of Staged Photography. Zurich: Edition Stemmle.

LIPOVETSKY, Gilles y CHARLES, Sebastien (2004). Los tiempos hipermodernos. Barcelona: Anagrama.

LIPOVETSKY, Gilles (2006). La felicidad paradójica: Ensayo sobre la sociedad de hiperconsumo. Barcelona: Anagrama.

MULVEY, Laura (2004). "Magnificent Obsession: Introducción a la obra de cinco fotógrafos”, en RIBALTA, Jorge (ed.), Efecto Real. Debates posmodernos sobre fotografía. Barcelona: Gustavo Gili, col. Fotografía, pp. 216-230.

PUELLES ROMERO, Luis (2002). Modos de la sensibilidad. Hiperrealidad espectacularidad y extrañamiento. Pontevedra: Diputación Provincial de Pontevedra, col. Arte y Estética.

SOLOMON-GODEAU, Abigail (1983). "Winning the game when the rules have been changed. Art photography and postmodernism”, en WELLS, Liz (ed.): The Photography Reader (2003). New York: Routledge, pp. 152163.

VV.AA. (2006). Vitamin Ph: New Perspectives in Photography. Londres: Phaidon Press.

VERDÚ, Vicente (2003). El estilo del mundo. La vida en el capitalismo de ficción. Barcelona: Anagrama.

VERDÚ, Vicente (2005). Yo y tú, objetos de lujo. El personismo: La primera revolución cultural del siglo XXI. Barcelona: Debate, col. Arena Abierta. 